\title{
ARTIGOS
}

\section{ARTE E CIDADE. CONSIDERAÇÕES CRÍTICAS SOBRE ARTE E VALOR NA SOCIEDADE DE CLASSES}

Ronaldo Rosas Reis* ronaldorosas@id.uff.br

RESUMO $O$ tema do artigo é a relação arte e cidade, mediante o qual busca-se estudar a conformação do valor da arte numa sociedade de classes. Sua estrutura parte de um recorte da pesquisa em curso no âmbito do estágio sênior na Faculdade de Filosofia e Letras da Universidade de Buenos Aires entre 2013 e 2014. O texto se desenvolve em tópicos de temáticas complementares onde são analisadas as categorias estatuto social da cidade, a mercadoria arte, a alienação e a banalização da criatividade com as dimensões econômico-política, estético-ideológica $e$ moral-educativa da arte que se encontram engendradas historicamente na totalidade das relações sociais de produção configuradas na cidade.

Palavras-chave Arte, Cidade, Estética, Ideologia, Educação.

ABSTRACT The theme of this paper is the relationship between art and city, through which we seek to study the conformation of the value of art in a society of classes. Its structure is a piece of a research in progress under the senior stage in the College of Philosophy and Letters of the University of Buenos Aires between 2013 and 2014. The text develops into topics where additional subjects are analysed categories of city bylaws, merchandise art,

* Universidade Federal Fluminense (UFF). Artigo recebido em 30/06/2014 e aprovado em 02/09/2014. 
alienation and the banalization of creativity with the aesthetic-ideological, economic-political and moral educational dimensions of art that are historically engendered in the totality of social relations of production set in the city.

Keywords Art, City, Aesthetics, Ideology, Education.

La ciencia se orienta a refigurar el ser como tal, en su forma más depurad, dentro de lo posible, de todo añadido subjetivo; mientras que el ser mentado por la posición estética es siempre el mundo del hombre (Lukács, 1967, p. 306)

Parte o presente ensaio de um recorte dos estudos realizados entre 2013 e 2014, no âmbito do nosso estágio sênior na Faculdade de Filosofia e Letras da Universidade de Buenos Aires como bolsista da Coordenação de Aperfeiçoamento do Pessoal do Ensino Superior (CAPES). Considerando a centralidade da cidade na conformação do valor da arte numa sociedade de classes, o texto foi desenvolvido em quatro tópicos de temáticas complementares nos quais são analisadas as seguintes relações: $a$ ) o estatuto da cidade e o valor da arte; $b$ ) a metamorfose da cidade: dinheiro e a mercadoria arte; $c$ ) utopias, autonomia e alienação; $d$ ) distopias do presente e banalização da criatividade. A esses tópicos segue-se um breve apontamento conclusivo.

Justifica-se a correspondência desse conjunto de questões dadas as dimensões econômico-política, estético-ideológica e moral-educativa da arte que se encontram engendradas historicamente na totalidade das relações sociais de produção configuradas na cidade. Portanto, de um lado, o nosso esforço aqui será o de expor a gênese das características gerais das dimensões sociais examinadas que se apresentam nas relações de produção, e, por outro lado, examinar de que forma a exploração do trabalho do artista no sistema capitalista e os atritos gerados no interior desse processo engendram a transformação do valor artístico de uso em mercadoria e reificam o saber da arte.

\section{Estatuto da cidade e valor da arte}

$\mathrm{Na}$ "Introdução a uma estética marxista", Lukács (1978) toma por base o conjunto da obra de Marx, em especial seus apontamentos sobre arte, para 
aprofundar a ideia da "arte como autoconsciência do desenvolvimento da humanidade" (pp. 282-298). Nesse sentido, ele compõe um percurso crítico do pensamento estético moderno a partir do que entende ser o seu marco inaugural, a revolução copernicana de Kant, cujo desenrolar impactará a filosofia alemã "[...] que nessa grande crise de crescimento do pensamento, principiou a colocar o problema da dialética e a buscar-lhe a solução" (idem, p. 8). Seu ponto de chegada e fulcro daquela obra e posteriormente da "Estética" (1967) é o exame da categoria da particularidade por ele considerada central da estética. Para o filósofo húngaro, por constituírem "um antigo problema do pensamento humano", é imperioso que se faça a distinção das categorias contidas nas "relações entre a universalidade, a particularidade e a singularidade" (op. cit., 1978, p. 5). Todavia, bem mais além do esforço fundador estabelecido na "Introdução" (op. cit., 1978), será no derradeiro capítulo da "Estética" que o filósofo húngaro irá expor as etapas principais da luta libertadora da arte (1967; vol. IV, cap. 16, pp. 368-576). Decerto que não é nosso propósito no momento, nem haveria espaço neste ensaio para nos estendermos na apreciação do percurso lukacsiano, dos seus desdobramentos e conclusões se não como inspiração e referência teórico-metodológica para que o nosso próprio percurso possa atingir o objetivo anunciado mais acima ao final da apresentação do presente trabalho.

Desde o seu aparecimento a polis tem sido identificada pela atividade singular na história da humanidade que é a luta travada no seu interior em torno da hegemonia pela condução da vida social. Por essa atividade entendase singular a condução das coisas espirituais, dos negócios comerciais e dos negócios da guerra e da morte. ${ }^{1}$ Dada a sua condição estrutural no modo como a comunidade humana se relaciona para produzir a sua existência e da totalidade da sociedade, desde logo temos a dimensão econômica e política como essencial - no sentido que a ontologia crítica confere a esse termo - em todo o processo. A conquista pública da lei e do saber significou na vida social da polis grega uma evolução de tal ordem cuja consequência mais visível foi a criação de um estatuto próprio da cidade. Base daquilo que ficaria conhecido como democracia ateniense, a unidade fundada nas ideias do múltiplo-semelhante e do diverso-igual orientaria doravante a episteme grega. Entretanto, se aquela evolução resultou da renúncia da unicidade do poder ditado pelos segredos das seitas que detinham a autoridade sagrada e o poder de regência sobre a cidade, a criação do estatuto da cidade trouxe implicações da guerra, e a guerra provocava a morte. Eles viviam literalmente com a morte” (2003, p. 14). 
éticas que acabariam por acrescentar àquela episteme uma dimensão moral e educativa.

Ao estender a disputa para o terreno ético, a cidade passaria a recusar e mesmo condenar os discursos ambíguos, dualistas, apaixonados, e todos os sentimentos subjetivos que inspiram o homem e o empurram sem direção ao acaso. Na defesa da sua unidade da cidade, o homem grego apreende negativamente a atitude subjetiva, os desvios da paixão e da imaginação o sentimento trágico por assim dizer - pois nelas enxerga uma ameaça ao seu sentido e por isso o condena. Com essa postura moral, o homem grego desenharia um projeto teleológico para a cidade a fim de construir uma nova episteme cujo objetivo último seria o de educar o olhar do homem. O que propunha era dirigir o olhar para o alto libertando-o das dores profundas causadas pela escravidão do trágico. É, portanto, no marco da recusa do sentimento trágico que a filosofia propõe a educação do olhar como um instrumento para o homem ascender ao plano da verdade. Foi caminhando nesse terreno ético que a metafísica acabaria se impondo com Platão, sendo no decorrer do tempo absorvida muito menos como uma proposição filosófica para se tornar um axioma do senso comum. Por tudo isso, o valor da arte se tornaria um risco, uma ameaça ao estatuto da cidade. Com efeito, de acordo com Lukács (1967), ao exigir da arte um critério de cientificidade para refletir a realidade de modo a corresponder "exatamente, sob qualquer ponto de vista, à relação entre a essência e a aparência, o conteúdo e a forma etc.” (p. 379), Platão afirmava, nesse sentido, que os poetas inspirados nada sabem do que dizem a respeito da realidade:

[...] esa actitud última de Platón muestra la tendencia básica de su estimación del arte: el arte tal como se ha desarrollado realmente en Grecia, como una desplegada imposición de la sustantividad de lo estético, tiene consecuentemente que desterrarse de la polis platónica (Lukács, 1967, p. 378).

Mais além da importância que a posição platônica de "anular mentalmente tudo o que específico da positividade estética" adquiriria com o tempo no corpo da história da filosofia (ibidem, p. 380), cabe dizer que ela foi determinante para que a cidade operasse mudanças no seu estatuto. De fato, na polis grega a condenação da arte e dos artistas não se faria sem debates apaixonados, sem o aparecimento de tensões, paradoxos e contrapartidas, por vezes incontornáveis e apreendidas como perigosamente desastrosas para a cidade. Entre aqueles que defendiam a tese de serem buscadas formas de integrar a arte na vida social se encontrava Aristóteles. Segundo Lukács (1967), a descoberta do filósofo da diferença entre o reflexo estético da realidade e a realidade ela mesma, assim 
como a relação daquele reflexo com a ética, teria sido decisiva para que ele considerasse o potencial político da arte numa sociedade já complexa como a grega. Entendia Aristóteles que ao refletir a realidade atribuindo qualidades humanas aos personagens, ao contexto, enfim à totalidade da obra de arte, o artista oferecia à polis a possibilidade de refletir sobre o seu éthos, isto é, seus valores, ideias e crenças, seja no sentido crítico (de ruptura) seja no sentido emancipatório. Assim convencido da função social da arte, Aristóteles tomaria para si a dupla tarefa de, por um lado, levar o artista a reconhecer a importância da dimensão ética do que produzia, e, por outro, buscar um novo significado para a educação dos sentidos da sociedade mediante a politização da arte. Para Aristóteles, tão fundamental quanto o reconhecimento da polis da importância epistemológica da arte no combate à "transcendência da doutrina platônica das ideias e toda doutrina teológica na ética" era que o artista elevasse o teatro, a poesia, a música à condição de despertar as "forças próprias de cada homem, para com a sua ajuda - e somente com ela - este possa mover-se no sentido do seu aperfeiçoamento" (ibidem, p. 380). A este propósito Lukács destacará que

La concepción aristotélica del arte puesta sobre esa base [la catarsis] no es menos social - menos nacida de la sociedad, menos capaz de desembocar en ella - que la de Platón; tampoco ella contrapone abstractamente el individuo a la sociedad, como tan a menudo ocurre en la estética moderna; pero en el pensamiento de Aristóteles la fuerza pedagógica social del arte nace de su propia consumación estética, y no, como en el pensamiento platónico, de la momificación o la simple supresión de los principios propiamente estéticos (1967, pp. 380-381).

A concepção de arte de Aristóteles inaugura um ideal educacional cuja finalidade seria a de estetizar a moral, e nessa perspectiva ideológica caberia ao artista a função educativa de elevar a tensão produtiva entre a estética e a política com o objetivo de se alcançar uma cultura reformada e a subjetividade revolucionada. Não por acaso essa concepção se entranharia na Antiguidade e ultrapassaria os seus limites históricos, acrescentando ao sentido e ao destino da polis uma nova dimensão social, a estética, de resto flagrantemente referenciada num projeto teleológico-educativo.

\section{Metamorfose da cidade: dinheiro e mercadoria arte}

A reinvenção da cidade pelo dinheiro é também a reinvenção do seu sentido e destino, enfim, das dimensões sociais nela engendradas pela totalidade das relações de produção. $\mathrm{O}$ chocante contraste entre a opulência burguesa e a crua indigência do proletariado no espaço da cidade expõe uma vida social marcada pela indiferença e pelo isolamento. Engels, em 1844, 
diria se tratar de uma visão "[...] chocante e perturbadora na medida em que esses indivíduos estão amalgamados em espaços cada vez menores" (apud Konder, 2000, p. 64). As revoluções de 1848, precedidas por levantes urbanos que se acumulavam por mais de duas décadas em diversas cidades europeias, explicitavam a crise estrutural da sociedade urbanizada e acabariam precipitando aquela que viria a se constituir na primeira e mais importante experiência burguesa de modernização de uma cidade: a reforma de Paris. Iniciada em 1852, a reforma urbana e arquitetônica da cidade foi dada por concluída em 1870, tendo como uma de suas finalidades facilitar as manobras militares após os conflitos de 1848. Entretanto, contribuiu ainda decisivamente para a reforma da cidade a combinação de interesses do Estado e dos rentistas desejosos de especular com os terrenos no centro urbano ocupados por trabalhadores, o desejo da burguesia de se manter longe do proletariado e da indigência ${ }^{2}$ Cumulativamente, a despeito do pertencimento de classe conformar a sua ideologia no âmbito mais geral do seu projeto teleológico, a burguesia tinha claro para si o seu fracionamento, fato que tornava ainda mais dura a luta política pelo controle e a direção do sentido e do destino da sociedade. É, portanto, em meio a relações sociais cada vez complexas que a filosofia e a arte irão se debater, ora juntas ora separadamente, à procura de uma episteme capaz de dar conta de um novo estatuto para uma sociedade ameaçada pela entropia. ${ }^{3}$

Do ponto de vista filosófico, a criação de uma nova cidade sobre as mesmas bases da anterior tinha por finalidade cumprir algo mais do que uma função modernizadora ao aterrar o seu passado medieval. Sua criação deveria expressar idealmente um valor. Sem embargo, a cidade seria então apresentada não como algo que foi reformado, mas sim como uma nova cidade cujo conceito de modelo universal expressava uma verdade histórica. Para um político esclarecido como Haussmann, encarregado por Luis Napoleão de conceber e levar adiante as obras de Paris, havia a percepção de que as ações humanas eram interdependentes e que estavam condicionadas dialeticamente pelas múltiplas determinações dos seus respectivos desenvolvimentos. É de se notar, nesse sentido, que no arcabouço das reformas das cidades e das instituições europeias se apresentava a ideia hegeliana de totalidade. Com efeito, quer

2 Walter Benjamin (2006), em “Passagens (1927-1940)”, e Victor Hugo (2012), em 1862, em “Os miseráveis”, descreveriam com acuidade, respectivamente, a Paris dos especuladores e a dos indigentes.

3 Note-se aqui, conforme a exposição que fizemos no início desta parte do texto, a correspondência entre a luta burguesa pela superação da crise estrutural da sociedade e a luta da filosofia diante da crise de crescimento do pensamento, marco que propiciará a Lukács uma tomada de reflexão sobre a centralidade da categoria da particularidade na estética. 
como conteúdo da história, contraditório, tenso, permanentemente relacional, vincado na contradição de toda ordem, quer como um continuum civilizatório a atravessar a história triunfalmente perpassa a ação modernizadora da cidade e de boa parte das instituições europeias no decorrer do século XIX, aquela ideia estava presente. Por conseguinte, a nova cidade deveria ser para futuras e sucessivas gerações um valor civilizatório que expressasse o éthos da uma sociedade orientada pela racionalidade. Correspondendo a esse telos ético o neoclassicismo e suas variantes estilísticas no âmbito da Academia emergiram como orientação estética oficial nas principais atividades que formavam o conjunto central da construção da nova cidade: o urbanismo, a arquitetura e o paisagismo.

Considerando a questão sob esse aspecto, a arte e a filosofia se alinhavam no esforço de erigir um modelo universal e secular na forma de uma cidade neoclássica tal como se apresentava. Cabe notar, entretanto, que o que se passa no ambiente da cidade reinventada pelo dinheiro é de uma ordem diferente do que se passou no ambiente da polis, mesmo depois do advento filosófico de Aristóteles. Nesta última o artista não tinha um lugar social formalmente definido, e a arte de um modo geral carecia de conceituações consagradas e de um sistema que a ordenasse e lhe permitisse um abrigo institucional. Já na cidade dividida socialmente pelo trabalho o artista não apenas conquistara um lugar social reconhecido, como a totalidade das relações de produção da arte já tinha engendrado um Sistema particular como uma das instâncias de acumulação de capital. ${ }^{4}$ Ora, na medida em que o desenvolvimento da arte em meio às relações de produção capitalista impôs condições distintas do que para a filosofia, o seu alinhamento com esta última resultaria ser pontual, durando o tempo necessário para que a nova cidade fosse absorvida na sua capacidade de impressionar e que se esgotasse o interesse especulativo dos negócios burgueses. Na cidade do dinheiro, o valor da arte abrigado no valor da cidade adquirira a forma transitória da mercadoria. Sob o modo de produção capitalista, o saber da arte tende à destruição e à autodestruição, e tanto maior será o poder de destruição e de autodestruição desse saber quanto mais aceleradas forem "as trocas entre o adquirido e o espontâneo" (Lefebvre, 2001, p. 170). Menos de um século depois de concluídas as reformas das grandes cidades europeias, a metrópole universal e secular conceitualmente

4 Em mais de um trabalho examinei a gênese do sistema de arte na transição do século XVIII para o XIX a partir das determinantes sociopolíticas, econômicas e culturais que se apresentavam. Da mesma forma, analisei criticamente a influência desse sistema na formação profissional do artista e seu reflexo no campo educacional em geral. Vide Reis (2010). 
erigida como modelo para o futuro “desmanchou-se no ar" (Marx, Engels, 2001).

A crítica humanista clássica ao atual abandono do Iluminismo fundador pelo homem moderno e dos valores que engendraram a sociedade burguesa, a liberdade, a igualdade e a solidariedade, não desconsidera certamente as próprias contradições e os desvios daquele humanismo que fizeram do presente o que hoje tanto criticam. No caso da arte, tal como foi apropriado daquele pensamento, o modelo estético de um saber cuja culminância devia ser refletida na cidade, nas instituições sociais, no Estado, pôs fim ao passado medieval sem ter se constituído num valor para a humanidade no presente e no seu desenvolvimento futuro. ${ }^{5}$ Nesse sentido, o modelo estético limitou-se à representação de si mesmo como modelo, e sua precária durabilidade durou o tempo necessário para ser contestado por tudo aquilo que na primeira metade do século XX foi chamado de vanguarda.

É verdade que, do ponto de vista da evolução da linguagem artística, rigorosamente em todos os campos da arte - Literatura, Artes Visuais, Música, Teatro etc. -, a burguesia logrou alcançar um modo próprio de expressão, bem distinto de tudo quanto antes fora produzido até algum tempo depois de a sua classe conquistar a hegemonia política na sociedade. De fato, numa sociedade orientada pela racionalidade em todos os seus meios, nada restaria dos dogmas religiosos e dos excessos frívolos de influência aristocrática que permearam toda arte desde o Renascimento. Conforme apontamos anteriormente, na segunda metade do século XIX as Academias de arte mantidas pelo Estado compunham parte do Sistema de Arte com o objetivo de avalizar, formar e reproduzir os valores estéticos da sociedade burguesa. A despeito disso e contra isso, no limiar do século $\mathrm{XX}$, uma extraordinária quantidade de tendências estéticas modernizantes irromperia de forma mais ou menos organizada na vida social.

Em termos do prestígio das Academias e dos valores estéticos que avalizavam esse fato não significou muita coisa, de resto porque, como notam Argan (1993) e Hobsbawm (1995), o gosto pelo academicismo seguiria sendo para o burguês vulgar e para a classe trabalhadora a principal referência estética da verdadeira arte. Todavia, o que tornou possível a progressiva assimilação das novas linguagens artísticas pelo grande público deveu-se ao fato de os artífices e os artistas daquelas tendências modernas estarem no seio própria existência individual” (p. 290). 
mesmo da produção manufatureira e industrial. Nesse sentido, provocariam uma revolução silenciosa mediante a espacialização de estilos artísticos na vida cotidiana que faziam avançar, paulatinamente, a gramática da arte compondo um novo conjunto linguístico. Acrescente-se a isso o fato de que a forma mercadoria subsumida nos edifícios, lojas e casas, nos talheres, louças, móveis, ferramentas e equipamentos urbanos, no vestuário, nos cartazes, jornais e revistas, enfim, por qualquer objeto produzido industrialmente ou mesmo artesanalmente, trazia as marcas linguísticas dos estilos modernistas e os massificava no cotidiano das pessoas.

A partir desse fenômeno de gradativa absorção social dos estilos modernistas - vale dizer, por baixo ou à revelia da autoridade da Academia -, eu deveria concluir este ensaio examinando, ainda que de modo mais breve do que o necessário, três aspectos relacionais que me parecem determinantes no exame do valor da arte no mundo capitalista: a relação entre a busca da autonomia da arte e o aprofundamento da tendência à destruição e à autodestruição do saber da arte; a relação entre a exploração do trabalho do artista/artífice e a subsunção total do objeto artístico à forma mercadoria; a relação entre a banalização da criatividade e o "alívio do pós-moderno" (Jameson, 1996, p. 317). Entretanto, penso que tendo analisado exaustivamente o segundo aspecto relacional em trabalhos mais e menos recentes, não faria sentido retomá-lo aqui. ${ }^{6}$ Sem embargo, sempre que o exame dos outros dois aspectos assim exigir, alguns elementos daquela análise serão incorporados.

\section{Utopias, autonomia e alienação}

Em pouco mais de vinte e cinco anos, aproximadamente, uma quantidade jamais vista de movimentos, tendências, impulsos artísticos de vanguarda destruiu praticamente tudo o que lhes parecia externo à esfera própria da arte. Seja para garantir a sua autonomia e identidade, seja para livrar o objeto da arte do que consideravam, por assim dizer, "impurezas" de toda ordem: literárias, filosóficas, psicológicas etc. O que eles perseguiam era um novo sistema linguístico, autônomo, que servisse aos meios e aos fins da arte. Contudo, faltaria a esses movimentos vanguardistas a percepção das contradições inerentes à sua própria condição de vanguarda, e nesse sentido esses movimentos seriam levados à sua autodestruição ao se voltarem uns contra os outros. 
Na já mencionada "Estética", Lukács (1967) aborda essa tendência destrutiva e autodestrutiva das vanguardas à luz da categoria estética da alegoria, cuja essência é o aniquilamento da realidade imediata, da realidade sensível (ibidem, pp. 423-474). Na sua dimensão mais ampla a alegoria está associada a "necessidades religiosas", bem entendidas como "expressão artística de um individualismo anarquista e niilista" (ibidem, p. 457). ${ }^{7}$ Para o filósofo húngaro,

[...] esos síntomas, que no carecen de importancia ni son tampoco meramente superficiales, no deben escondernos el hecho básico de que las vivencias subyacentes a la mayoría de los grandes y característicos productos del arte de vanguardia proceden de necesidades religiosas, por lo que también su configuración está determinada por el contenido de dichas vivencias (idem).

Lukács (1967) observa que sendo a dualidade entre forma e conteúdo a principal característica da alegoria, sobressai entre as vanguardas uma concepção de autonomia limítrofe designada pela ideia da arte pela arte. Para ele decorre disso um formalismo estético cujo efeito é imanente, meramente espiritual e esvaziado de sentido em face da realidade imediata. De fato, o formalismo estético foi talvez a característica principal das mais importantes tendências vanguardistas, adotassem elas a representação figurativa ou não figurativa, e impôs a arte moderna uma forte característica decorativa, fato que não passaria despercebido do filósofo húngaro. ${ }^{8}$ Seu interesse por isso decorre do seu entendimento da proximidade entre a alegoria e o decorativo como categorias estéticas pertencentes à estrutura mesma da arte. Tentarei abordar 0 assunto de forma resumida.

De acordo com Lukács (1967), dado o fato de o aparecimento do princípio decorativo na arte ter ocorrido de forma espontânea muito antes do objeto ou da figura autônoma - nas pinturas rupestres, por exemplo -, teria dado ao decorativo, mais amplitude e abrangência do que coube à alegoria. ${ }^{9}$ Contudo, sublinha Lukács que o limite da transcendência do decorativo (como processo mediador da realidade) é a sua não cristalização em um conteúdo, fato que

7 Embora fora do escopo deste ensaio, não posso me furtar em dizer que é tentador o exercício comparativo entre a ação das vanguardas artísticas e a estética da violência performática dos atuais grupos anarquistas, como os Black blocs.

8 A propósito do decorativo na pintura, consta do anedotário da arte moderna a resposta que Matisse teria dado a uma reclamação sobre a cor verde pintada como pele de uma figura feminina num dos seus quadros: "não é uma mulher, é uma pintura", teria dito o artista.

9 O filósofo aqui faz referência à questão da mimese autêntica, isto é, como processo de antropomorfização que no decorativo comparece espontaneamente evocando a representação e a sensação de realidade (ibidem, p. 431). 
o levaria necessariamente a produzir algo alegórico (ibidem, p. 434). Cabe ressaltar que a característica específica do conteúdo a que o filósofo faz aqui referência criticamente é aquela que ao buscar dar uma nova configuração ao mundo acaba desfigurando a realidade, tornando o objeto artístico vazio de sentido. Nesse sentido, o filósofo dirá que contrariamente à transcendência religiosa da "velha alegoria" estudada por Walter Benjamin (ibidem, p. 468), a religiosidade da alegoria das vanguardas modernistas se volta tão somente para a destruição da realidade imediata. Por conseguinte, na extensão do seu exame do problema das vanguardas, Lukács dirá que é nessa medida da contradição entre a destruição do mundo e a sua recriação pela arte que o formalismo estético das suas propostas se mostra inócuo. Para ele se trata de uma reconfiguração do mundo sem mundo, "uma articulação abstrata da singularidade privada e generalidade abstrata, que se chega a ter uma eficácia duradoura, isso somente ocorre ao nível do decorativo vazio de conteúdo" (ibidem, p. 443). ${ }^{10}$ Reforçando essa análise, Argan (1992) escreveria que

[...] como parte de um sistema cultural fundado na racionalidade, na consciência dos seus limites e na complementaridade natural da imaginação ou fantasia [...], trazia o signo de uma dedução final e constituía o documento desesperador de uma civilização em crise (p. 507).

Aintenção de revolucionar de forma permanente a linguagem artística levou a vanguarda a uma dupla operação que geraria uma contradição incontornável. De um lado, submeteu a arte a uma ideologia estética pensando em destruir a própria arte e, com ela, o âmago do Sistema. De outro, querendo inserir a arte no seio da vida social alienou o trabalho de arte na produção de artefatos. A arte se manteve viva, porém no sentido oposto do pretendido. O caráter alegórico da nova produção artística acentuou a tendência anti-humanista que preside as relações sociais no capitalismo, o Sistema de Arte absorveu o golpe e ajustou a sua tábua de valores metamorfoseando o seu telos e, desde então, na medida em que as oportunidades se apresentam, a exploração da mais-valia do trabalho de arte o deslocou da categoria improdutiva tout court. Desde então, consolidada a ideia de que arte é mercadoria, temos naturalizado o valor de troca como determinante principal do valor da obra de arte.

10 Cabe esclarecer que Lukács toma como objeto central da sua análise o conjunto geral das propostas e da produção dos movimentos vanguardistas. De certo modo ele desconfia da necessidade de os estetas marxistas levarem adiante a tarefa de examinar amiúde a produção, entre outros, de artistas "tão talentosos e potentes como Matisse e Picasso", segundo o filósofo "tão frequentemente presos em uma experimentação problemática" (ibidem, p. 472). 


\section{Distopias do presente e banalização da criatividade}

Em 1981, o artista alemão Martin Kippenberger expôs numa bienal de arte uma de suas mais conhecidas e controvertidas obras, "Dialog mit der jungend" ("Diálogo com a juventude"). Desde então a peça vem sendo exibida regularmente em galerias, museus, bienais e feiras de arte em todo o mundo. Trata-se de uma reprodução fotográfica em tamanho natural do rosto espancado de Kippenberger, o objeto fotografado. A imagem mostra uma espessa ligadura na cabeça a esconder os cortes sofridos pelo artista, sem ocultar, entretanto, as marcas da violência em seus olhos, nariz, orelhas e boca. Segundo Kippenberger informou na ocasião, o trabalho fazia parte de um projeto amplo no qual ele se propunha a desenvolver um "programa lúdico para desmascarar as aparências enganadoras que, como uma névoa ilusória e impenetrável, envolve a existência humana" (Honnef, 1988, p. 122). A despeito do fraseado sem sentido, mas de forte apelo publicitário, a origem da fotografia e da sua apresentação como trabalho artístico foi por muitos anos alvo de inúmeras controvérsias, o que de resto inflou a publicidade em torno da obra e a mitificação do artista. ${ }^{11}$ Com efeito, desde a sua morte em 1997, suas obras têm sido expostas regularmente, tendo a cidade de Berlim abrigado, em 2013, uma exposição retrospectiva do artista com mais de três centenas de suas obras incluindo "Diálogo". Como tem sido habitual nesse tipo de evento, adiante da sua própria obra, Kippenberger é apresentado pelos curadores da mostra e pelo jornalismo de entretenimento como um enfant terrible do Sistema, categoria máxima consignada na atualidade a um artista no sistema de arte. Dado que a cotação dos seus trabalhos na renomada empresa de leilões Christie está situada na faixa de U\$ 1.600.000, tendo o seu retrato espancado alcançado a cifra acima dos dois milhões de dólares, o mérito de Kippenberger está plenamente justificado.

Decerto que o breve exemplo que utilizei aqui como ilustração não chega a ser suficiente para dar conta da totalidade da arte na atualidade, contudo, não resta dúvida de que ele representa e sintetiza o amplo conjunto de experiências estéticas que tem estendido as práticas vanguardistas até os dias de hoje. Note-se aqui que, do ponto de vista histórico, a materialidade da performance do artista está constituída numa dimensão em que o meio social dela se apropria mediada pela indústria do entretenimento, e o seu valor passou a ser determinado pela escala de produção de bens de consumo agregados. ${ }^{12}$

11 Fonte: O Globo, segundo caderno, 19 maio 2013.

12 De fato, desde que Kippenberger alcançou o píncaro no Sistema, seu rosto mutilado, juntamente com o restante de suas obras, agregou valor e está reproduzido à exaustão em livros, cartazes, blocos de notas, canecas, camisetas, chaveiros etc. à venda no mercado dos museus e salas de exposição. 
Nesse sentido, cabe aqui recordar as palavras de Lukács (1967) a propósito da natureza conformista da arte de vanguarda:

[...] con la ayuda de la publicidad, del comercio de arte y de un verdadero terror periodístico han conseguido dominar la llamada opinión pública de la intelectualidad, muestra claramente cuál es la componente de su misión social: producir un atractivo confort para la sociedad capitalista de nuestros días. En un anterior contexto hemos hablado de la contradicción entre el inconformismo superficial y el conformismo de la actitud básica y última. En el merecido y masivo éxito de principios decorativos de ese tipo se manifiesta con toda claridad la esencia conformista como núcleo social de esas tendencias (p. 474).

Teríamos muito mais a dizer acerca do papel mediador da cadeia produtiva da indústria do entretenimento, incluindo, principalmente, os meios de comunicação. Todavia, a fim de concluir este trabalho, penso ser importante retomar a indagação inicial sobre o sentido e o destino da arte examinando algumas das implicações principais das experiências estéticas vanguardistas no presente.

Não deixa de ser verdadeiro que submetidos a um exame detalhado da particularidade dos movimentos vanguardistas revela que a sua negatividade estética em relação à arte potencializou ideias libertadoras nos mais variados setores da cultura burguesa. Em contrapartida, no reino da necessidade, aquela negatividade acabaria sendo transformada em positividade na medida do interesse que seus artefatos despertavam para atividades mundanas, e nesse sentido seriam incorporadas à produção industrial. Percebe-se aí uma dupla operação no processo de mediação social, a partir do que resulta, resumidamente, a ideia de que as vanguardas não tomaram consciência da inoperância política das suas ideologias estéticas revolucionárias, nem perceberam que ao insistirem nelas alimentavam as suas contradições internas. Dessa forma, no cotidiano das relações sociais, a penetração do reino simbólico pelo imperativo do lucro à exigência do Novo e da novidade se fez combinadamente na perspectiva programática de uma cultura da obsolescência visando à intensificação do consumo de objetos. Já no campo artístico, o reflexo da negatividade estética inaugural se aprofundou a ponto de banalizar a exigência permanente do Novo e da novidade. Por extensão lógica, em ambos os casos, fica evidente a banalização de tudo aquilo que um dia foi chamado de criatividade. É um mundo em que os objetos assumem a condição de um daemon ex machina a ditar o seu sentido e destino (Fischer, 1983, p. 96).

Poderia mencionar uma quantidade extraordinária de experiências estéticas cuja criatividade banalizada segue a linha de "Diálogos", mas me fixarei num breve exemplo doméstico que ganhou notoriedade na década 
de 1960 com o título de "Do porco empalhado ou dos critérios da crítica", escrito pelo crítico de arte Mário Pedrosa (2007). Em seu relato, Pedrosa descreve a situação de um artista paulista que havia submetido uma obra ao júri de uma importante exposição em Brasília. Tendo sido aprovada a obra, um porco empalhado dentro de um engradado de madeira, o artista então publicou nos jornais de São Paulo uma carta contra o júri condenando este último pela aprovação. Na carta, o artista criticava a ignorância do corpo de jurados por não ter conseguido distinguir aquilo que se tratava de um teste, uma brincadeira, de uma obra verdadeira. Em nome do corpo de jurados, Mário Pedrosa responderia ao artista publicando um longo artigo no qual ele esclarecia que, no seu modo de ver, a ideia de testar o júri e a publicação da carta tinha tanta importância quanto o próprio porco empalhado. Destacava o crítico que a espacialização da criatividade, demonstrada pelo artista na sua intenção (ou projeto) de testar o júri, estava compreendida no contexto libertário da negatividade estética das vanguardas artísticas no século XX, sendo este, para Pedrosa, um critério decisivo para a aceitação do porco empalhado. Sendo ou não cinismo a palavra-chave para definir esse conjunto de atitudes - na verdade para o contexto geral isso pouco importaria -, certo é que, em oposição a essa perspectiva, devemos considerar que, ao repetir indefinidamente a negatividade estética da atitude inaugural das vanguardas modernistas, as experiências estéticas mais recentes não fazem mais do que revelar uma trágica evolução da arte moderna e expressar a ausência de limites para o processo de desumanização da arte (Eagleton, 1993).

\section{Conclusões}

Fosse isso tudo a ser dito a propósito do valor da arte na atualidade, possivelmente ficaria aberto um flanco para se pensar que toda crítica à atitude das vanguardas se faz a partir das mesmas referências aqui dispostas e com o mesmo propósito reflexivo. Muito pelo contrário, houve um tempo, há pouco mais de 30 anos, em que diversos setores conservadores da crítica de arte reagiram contra a influência do darwinismo linguístico que, diziam, estava na base do pensamento das vanguardas artísticas da primeira metade do século XX. Traziam a crença de que a sua oposição ao modernismo resultaria num avanço do sentido e do destino da arte. Com efeito, tomando por referência teórica mais próxima a recusa pós-estruturalista à categoria da totalidade que preside o conjunto de metanarrativas - de Hegel a Marx e a Freud passaram a divulgar que a reação ao pensamento vanguardista começaria pela condenação da história para preservar a arte (Oliva apud De Fusco, 
1988). Defendiam a necessidade de colocar um termo no racionalismo que impregnara a arte moderna e propunham que o artista adotasse uma atitude nômade diante da história da arte, significando isso, na prática, um retorno ao ecletismo. Segundo um dos líderes dessa reação, o artista deve "abandonar os cânones do moderno em favor do clássico e repudiar os anos efervescentes de sua anarquia para inscreverem-se numa nova academia [...], o artista [deve] deixar de viver dentro da história para viver dentro da arte" (Tomassoni apud De Fusco, 1988).

Ao fundo da extraordinária produção teorética conservadora que buscava justificar o redirecionamento do sentido da produção artística a fim de ajustála às concepções de mundo anti-historicistas então emergentes, vislumbravase a necessidade de recuperação do mercado de arte, duplamente afetado no início dos anos de 1970. De fato, por um lado, desde o final da Segunda Guerra Mundial, quando então o acervo geral da arte moderna pode ser enfim catalogado - incluindo um significativo conjunto de registros documentais de obras efêmeras do vanguardismo mais radical -, a estrutura do mercado de arte pouco se alterara. Do ponto de vista do espaço físico as galerias de arte mantinham-se relativamente modestas e o investimento em museus públicos ou não era limitado para abrigar propostas de instalações, performances etc. Além disso, dadas as características de grande porte e/ou efêmeras das obras, o conhecimento sobre como lidar comercialmente com essa nova complexidade era igualmente limitado. Por outro lado, a crise estrutural global experimentada no início dos anos 1970 havia levado os investidores habituais no mercado de arte a refrearem as suas transações. Desse modo, a reação conservadora ao modernismo visava, sobretudo, garantir ganhos ao capital ganhando tempo para o mercado realizar os ajustes necessários e recuperar investidores. Por esse ângulo a proposta de retomada ganharia a força de um slogan publicitário, pretendendo-se de um só golpe retomar as formas de expressão e seus suportes tradicionais: a pintura, o desenho, a escultura. Enfim, o que se apresentava como francamente antitético acabaria se mostrando desonestamente reativo.

Se utilizei o exemplo acima foi apenas para reforçar a ideia de que no capitalismo o valor da arte é o que advém da exploração do trabalho do artista e da forma mercadoria da sua produção. Dessa forma, qualquer mudança operada no sentido e no destino da arte é para mantê-la do mesmo jeito. Por conseguinte, enquanto esse regime se mantiver, foge ao escopo de uma atitude crítica de oposição imaginar a humanidade resgatando a arte do labirinto em que foi encerrada, e muito menos a arte salvando a humanidade. Isso não significa, decerto, um impedimento ao artista para que ele busque no exercício contra-hegemônico um valor mais alto para a arte que é a luta 
pela liberdade. Nos termos de uma sociedade obcecada por mercadoria, a pergunta que se impõe é como ela pode fazer isso sem resvalar no proselitismo anódino dos discursos pedagógicos redundantes, ou na propaganda política de apelo emocional e ineficaz, de resto formas alegóricas que mais revelam o sintoma do desespero sem, contudo, elevar o espírito do indivíduo. Em regra, as experiências estéticas que examinamos e criticamos em boa parte deste trabalho caminharam no sentido inverso da arte que verdadeiramente conta - como Lukács se referia à "arte realmente grande" (1978, p. 291). Em verdade ao reduzirem tudo aquilo que é particular do estético ao Eu individual produziram uma arte em que o excesso formalista modernista e/ou o mero apelo hedonista da arte mais recente se mostra absolutamente ineficaz para se tornar algo essencial à vida e para a existência individual. Para manter viva a luta da arte pela emancipação humana sem os desvios românticos, e longe do cinismo que marca a atitude estética de boa parte dos artistas na atualidade, torna-se necessário e urgente que o artista do presente busque mediar na experiência estética a tensão entre a realidade vivida e a vida social.

\section{Referências}

ARGAN, G. C. “A história da cidade como história da arte". São Paulo: Ed. Martins Fontes, 1992. Tradução para o português: Pier Luigi Cabra.

ARGAN, G. C. "Arte moderna”. São Paulo: Ed. Martins Fontes, 1993. Tradução para o português: Denise Bottmann e Frederico Carotti.

BENJAMIN, W. "Magia e técnica, arte e política". In: Obras escolhidas. São Paulo: Ed. Brasiliense, 1985. Vol. 1. Tradução para o português: Sergio Paulo Rouanet.

BENJAMIN, W. "Passagens (1927-1940)". Belo Horizonte: Ed. UFMG, 2006. Tradução para o português: Irene Aron e Cleonice Mourão.

BORHEIM, G. "A inexorabilidade da morte In Revista de Filosofia SEAF". Ano III, Nr. 3. Rio de Janeiro: Sociedade de Estudos e Atividades Filosóficas, seção Rio de Janeiro, 2003, pp. 14-23.

DE FUSCO, R. "História da arte contemporânea". Lisboa: Edições 70, 1988. Tradução para o português: Maria Jorge Vilar de Figueiredo.

EAGLETON, T. “A ideologia da estética”. Rio de Janeiro: Jorge Zahar Editor, 1993. Tradução para o português: Mauro Sá Rego Costa.

FISCHER, E. “A necessidade da arte”. Rio de Janeiro: Ed. Zahar, 1983. Tradução para o português: Leandro Konder.

HOBSBAWM, E. "A era dos extremos. O breve século XX”. São Paulo: Cia das Letras, 1995. Tradução para o português: Maria Célia Paoli.

HONNEF, K. “Arte contemporânea”. São Paulo: Taschen, 1988. Tradução para o português: Casa das Línguas Ltda. 
HUGO, V. “Os miseráveis”. 2 volumes. 4a edição. São Paulo: Cosacnaif, 2012. Tradução para o português: Frederico Ozanam Pessoa de Barros.

JAMESON, F. "Pós-modernismo. A lógica cultural do capitalismo tardio". São Paulo: Ática, 1996. Tradução para o português: Maria Elisa Cevasco.

KONDER, L. “Os sofrimentos do homem burguês”. São Paulo: Ed. SENAC-SP, 2000. KONDER, L. "Os marxistas e a arte". Rio de Janeiro: Civilização Brasileira, 1967. LEFEBVRE, H. "A cidade do capital". Rio de Janeiro: Ed. DP\&A, 2001. Tradução para o português: Maria Helena Rauta Ramos e Marilena Jamur.

LUKÁCS, G. "Estética". Vol. 4. Barcelona: Grijalbo, 1967. Tradução para o espanhol: Manuel Sacristán.

LUKÁCS, G. "Introdução a uma estética marxista". Rio de Janeiro: Civilização Brasileira, 1978. Tradução para o português: Carlos Nelson Coutinho e Leandro Konder.

MARX, K. "Contribuição à crítica da economia política". 3a edição. São Paulo: Ed. Martins Fontes, 2003. Tradução para o português: Maria Helena Barreiro Alves.

MARX, K. "Manuscritos econômico-filosóficos". São Paulo: Boitempo, 2004a. Tradução para o português: Jesus Ranieri.

MARX, K. "O capital. Livro 1, volume 1". Rio de Janeiro: Civilização Brasileira, 2004b. Tradução para o português: Reginaldo Sant'Anna.

MARX, K., ENGELS, F. “A ideologia alemã”. São Paulo: Martins Fontes, 2001. Tradução para o português: Luís Cláudio de Castro e Costa.

OLIVA, A. B. "Transavantgarde international”. Milão: Giancarlo Politi, 1982.

PEDROSA, M. "Mundo, homem, arte em crise". São Paulo: Perspectiva, 2007. PONTUAL, R. "Explode geração". Rio de Janeiro: Avenir, 1984.

REIS, R.R. "Trabalho, arte e educação. Notas sobre a dualidade do ensino de arte". In: M. Ciavatta, R. R. Reis. A pesquisa histórica em educação. Manaus/Brasília: EDUAM/Ed. Líber, 2010. 